Article

\title{
The Impact of Residential Combustion Emissions on Health Expenditures: Empirical Evidence from Sub-Saharan Africa
}

\author{
Aboubacar Badamassi ${ }^{1, *}$, Deyi Xu ${ }^{1}$ and Boubacar Hamidou Leyla ${ }^{2}$ \\ 1 School of Economics and Management, China University of Geosciences, Wuhan 430074, China; \\ xdy@cug.edu.cn \\ 2 Key Laboratory of Tectonics and Petroleum Resources of Ministry of Education, China University of Geosciences, \\ Wuhan 430074, China; leyla_boubacar@yahoo.fr \\ * Correspondence: aboubacarbadamassi@yahoo.fr
}

Received: 6 July 2017; Accepted: 22 August 2017; Published: 25 August 2017

\begin{abstract}
Residential combustion of fuels, especially solid, for cooking, heating and other activities generates high level emissions that considerably contribute to indoor and outdoor air pollutants concentrations, which adversely affect human health and are likely to influence heath expenditures. We used the system General Method of Moments (GMM) technique to examine the role of residential combustion (proxied by: particulate matter $\left(\mathrm{PM}_{2.5}\right)$, carbon monoxide $(\mathrm{CO})$, nitrogen oxide $\left(\mathrm{NO}_{\mathrm{x}}\right)$ and sulphur dioxide $\left(\mathrm{SO}_{2}\right)$ emissions) in determining health expenditures while controlling for ambient air pollutants emissions from the other categories such as transportation, manufacturing industries and construction, and others. We employed data covering the period 1995-2010 in 44 countries of Sub-Saharan Africa (SSA). Health expenditures are categorized into per capita, public and private out-of-pocket; and we run three separate regressions according to the categories. The findings indicate that residential sector combustion was significantly associated with higher health expenditures, especially the out-of-pocket compared with other categories. Moreover, $\mathrm{PM}_{2.5}$ is found to have the highest impact on health expenditures. The implementation of effective public health and environmental health policies that encourage the access and use of cleaner fuels or improved cook stoves in SSA would be associated with not only a reduction in healthcare expenditures but also with other health and socio-economic benefits.
\end{abstract}

Keywords: residential combustion; emissions; biomass fuels; solid fuels; health expenditure; General Method of Moments (GMM); Sub-Saharan Africa (SSA); out-of-pocket health expenditures

\section{Introduction}

Residential sector combustion, especially of solid fuels such as coal (fossil fuel) and wood, dung, crop waste, and other agricultural residues (biomass fuels) for cooking, heating, lighting and other activities is a significant source of air pollutants emissions in Sub-Saharan Africa. In addition, $82 \%$ of Africans cook primarily with solid fuels [1]. The majority of these people are living in rural areas where they do not have access to modern forms of energy. Inefficient burning of these solid fuels using traditional cooking stoves or in an open fire generates smoke that contains various and important amounts of toxic pollutants. These pollutants include carbon monoxide (CO), particulate matter $\left(\mathrm{PM}_{2.5}\right.$ and $\left.\mathrm{PM}_{10}\right)$, nitrogen oxide $\left(\mathrm{NO}_{\mathrm{x}}\right)$ and sulphur dioxide $\left(\mathrm{SO}_{2}\right)$, which constitute a threat to the health of people, particularly women and young children who spend most of their time in the household [2] where exposure to concentrations of air pollutants from residential emissions is high. The main health effects associated with the exposure to concentrations of air pollutants from emissions are lung cancer, stroke, heart disease, chronic bronchitis, lower respiratory infections, cataracts, 
low birth weight, premature mortality, among others [1]. By contributing to damaging people's health, residential combustion is expected to be associated with more health expenditures. While most studies on residential combustion in developing countries have focused on the health effects of exposure to emissions from the burning of solid fuels, little is known about the healthcare expenditure impacts. This paper attempts to assess the effects of residential combustion emissions on health expenditures in Sub-Saharan Africa countries using empirical approaches.

\section{Background}

The combustion of solid fuels highly dominates the residential emissions in Sub-Saharan Africa. Today, the reliance on polluting energy sources like wood, charcoal and dung for cooking is high and amounts to more than 3 billion people worldwide [3]. An estimated 700 million Africans cook primarily with solid fuels (and 850-900 million will do so by 2020) [1]. The results of a survey from 18 African countries, members of the World Health Organization (WHO), indicate that a substantial share (more than 95\%) of all households rely mainly on biomass fuels for cooking [3]. Emissions from residential combustion are harmful to health, especially within households where there is poor ventilation or inappropriate design of stoves that do not have hoods or flues to evacuate the smoke, which resulted from incomplete combustion out of the house. Inefficient burning of solid fuels emits health-damaging toxic products such as particulate matter $\left(\mathrm{PM}_{2.5}\right.$ and $\left.\mathrm{PM}_{10}\right)$, carbon monoxide $(\mathrm{CO})$, oxides of nitrogen $\left(\mathrm{NO}_{\mathrm{x}}\right)$ and sulphur dioxide $\left(\mathrm{SO}_{2}\right)$. The particulate matter is categorized based on its size. Thus, $\mathrm{PM}_{10}$ means particulate matter with aerodynamic diameter less than $10 \mu \mathrm{m}$ while $\mathrm{PM}_{2.5}$ is of less than $2.5 \mu \mathrm{m}$ of diameter. Residential sector combustion contributes to indoor and outdoor air pollution. Meanwhile, 50 and $25 \mu \mathrm{g} / \mathrm{m}^{3}$ are the 24-h average particulate matter levels set in the WHO guidelines for indoor air quality for $\mathrm{PM}_{10}$ and $\mathrm{PM}_{2.5}$, respectively [4]. However, in the majority of the Sub-Saharan African countries the concentrations of PM far exceed these guidelines. For instance, in rural Kenya, peak concentrations are greater than $50,000 \mu \mathrm{g} / \mathrm{m}^{3}$ in the proximity of the cooking fire [5-7]. There exist considerable age, gender as well as socioeconomic differences in levels of exposure and the related health effects [8]. Moreover, emissions from residential combustion contribute to the degradation of air quality with adverse implications for human health that are likely to drive health expenditures up, which, in turn, will likely be at the expense of other sectors' expenditures such as education.

Sub-Saharan Africa is already a large cooking market: US $\$ 20$ billion was spent annually on cooking fuels in 2010, and US\$300-400 million was spent on all types of stoves. By 2020, fuel spending is set to more than double to US $\$ 47$ billion [1]. Solid fuel cooking in Sub-Saharan Africa accounts for $6 \%$ of global black carbon emissions and $1.2 \%$ of carbon dioxide emissions [1]. Four factors are identified to be essential in household decision making on the use of fuel type: (1) the cost of fuel, the type of stove and access conditions to fuels; (2) technical features of cooking-stoves and cooking practices; (3) culture-based preferences; and, finally, (4) health impacts [9].

Furthermore, this study uses the system General Method of Moments (GMM) to quantitatively explore the nexus between emissions from residential combustion and health expenditures. The following details provide insights on the background of the model. The Arellano-Bond [10] and Arellano-Bover [11]/Blundell-Bond [12] are all dynamic panel estimators that are designed to be applied in situations with (a) few time periods (small T) and many individuals (large N panels); (b) a functional relationship that is linear; (c) a single left-hand-side variable that depends on its own past values; (d) not strictly exogenous independent variables, which means correlated with past and possibly current values of the error; (e) fixed individual effects; and (f) heteroskedasticity and autocorrelation within individuals but not across them.

Arellano-Bond estimation first transforms all regressors, generally by differencing, and uses the Generalized Method of Moments [13], and hence is called Difference GMM. Then, the Arellano-Bover/Blundell-Bond estimator makes an additional assumption that first differences of instrument variables are uncorrelated with the fixed effects to augment Arellano-Bond. 
Thus, this permits the introduction of more instruments, which can lead to a dramatic improvement of efficiency; and builds a system of two equations including the original equation as well as the transformed one, which is thus called System GMM [14].

\section{Literature Review}

Most of the previous work related to emissions from residential combustion focused on the health effects of the exposure to the toxic pollutants concentrations. A detailed discussion of the health impacts resulting from exposure to air pollutants emissions products is not within the scope of this paper, and only some general aspects seen necessary are outlined as the main interest is the residential combustion-health expenditures nexus. We cannot review all the studies in this section; but, in the following, we show evidence of the link between a high risk of respiratory illness, lung disease, cardiac events, stroke, eye disease, meningitis, tuberculosis (TB), low birth weight, nutritional deficiencies and premature mortality with air pollution [5,6,15-32].

In addition, literature concerning the factors determining health expenditures is substantial. Meanwhile, this literature has examined various determinants of health expenditures, including the proportion of health care publicly funded, income, population aging, the amount of foreign aid, the number of practicing physicians, the participation rate of female labor force, the rate of urbanization, among other non-economic factors (among others, see [33-42]).

However, studies closer to this paper are in [43,44]. Jerrett et al. [43] explored the nexus between environmental quality and health care expenditures. Total pollution emissions and government expenditures allocated to protecting environmental quality were considered as a proxy for environmental quality. The study employed cross-sectional data from 49 counties of Ontario (Canada), and the findings revealed that counties with higher pollution output have higher per capita health expenditures while counties that provide more financing for protecting environmental quality have lower health care expenditures.

Narayan et al. [44] examined the role of environmental quality in the determination of per capita health care expenditures. They used a panel cointegration technique in order to investigate the possibility of estimating both short-run and long-run effects of environmental quality based on eight OECD countries covering the time period 1980-1999. They found that per capita health care expenditures, per capita income, carbon monoxide, sulphur oxide and nitrogen oxide emissions are panel cointegrated. While the short-run elasticities indicate significant positive effects of income and carbon monoxide emissions on health care expenditures, in the long-run, their findings revealed that income, carbon monoxide and sulphur oxide emissions affect health care expenditures with significant and positive signs.

The contribution of this study is twofold. Firstly, this paper established empirical relationships between residential combustion and health expenditure according to different categories, in order to have a clearer picture of the relationships and help in policy making. Then, methodologically, a system (two-step) generalized method of moment (two-step GMM) techniques is applied to panel data, which takes into account endogeneity and time lags effects. The advantages of this method are given in details in the methodology section. Previous studies did not cover these important aspects.

\section{Experiments}

\subsection{Data}

The dataset comprises 44 Sub-Saharan African countries for the period 1995-2010. The availability of data determining the sample and the time series data are collected on an annual basis (see Table A1 in Appendix A for the list of countries included in the sample).

The health expenditures variables used are: per capita health expenditure (HEPC), private out-of-pocket health expenditure scaled as a percentage of total health expenditures (OOPPTHE) and public health expenditures also measured as a percentage of total health expenditures (HEPUBTHE). 
In addition to emissions from residential combustion (main category of this study), we also used the ambient emissions data from all the other categories (which we categorized as manufacturing industries and construction, transportation and others) provided in the data set (EDGARv4.3.1, European Commission, European Union; and description is given below). Emissions variables are carbon monoxide $(\mathrm{CO})$, nitrogen oxide $\left(\mathrm{NO}_{\mathrm{x}}\right)$, sulphur dioxide $\left(\mathrm{SO}_{2}\right)$ and particulate matter $\left(\mathrm{PM}_{2.5}\right)$ emissions. Their annual emissions are in gigagrams $(\mathrm{Gg})$.

While data on emissions variables are available for the period before 1995, data on health expenditures are not available. Furthermore, data on emissions variables are not available for the period post-2010, whereas health expenditures data are available.

Moreover, data on health expenditures and emissions from residential combustion are the main variables of this study. The ambient emissions from the remaining categories, per capita GDP growth rate (GDPPCGR), population growth rate (PGR) and per capita development assistance for health (DAHPC) are used as control variables. Except for GDPPCGR and PGR, which are already expressed in percentages, all of the variables are converted into logarithmic form before the analyses.

Emissions variables are sourced from EDGARv4.3.1 (Emissions Database for Global Atmospheric Research version v4.3.1; [45] which was the latest release at the time of writing this paper; DAHPC data come from the Institute for Health Metrics and Evalution (IHME) 2015 database and all the remaining variables are sourced from the world development indicators (WDI) of the World Bank.

EDGARv4.3.1 is used as the reference inventory of anthropogenic emissions, providing historical emission time series data for $\mathrm{SO}_{2}, \mathrm{NO}_{x}, \mathrm{CO}$, total non-methane volatile organic compounds (NMVOCs), $\mathrm{NH}_{3}$, as well as particulate matter compounds, namely $\mathrm{PM}_{10}, \mathrm{PM}_{2.5}$, Black Carbon (BC), Organic Carbon (OC).

EDGARv4.3.1 relies on international energy balances of IEA (2014) and agricultural statistics of the Food and Agricultural Organization (FAO) (2012) and regional or national information and assumptions on technology use and emission control standards [46].

Fuel production and combustion statistics obtained from the International Energy Agency (IEA) database are used to calculate energy-related emissions, which include combustion in the energy, manufacturing and transformation industries, combustion in oil refineries and the residential sector; and information from the Food and Agricultural Organization (FAO) (2011) was used for agricultural waste burning.

EDGARv4.3.1 is one of the few global emission inventories with consistent methodologies to calculate emission time series covering four decades for air pollutants. However, these data are non-quantifiable from local studies; use surrogate parameters as indirect indicators for emissions; have a coarse spatial averaging and are not updated in regular temporal intervals; and do not have scientific or regulatory endorsements from any national or international organization representing the local population.

\subsection{Model}

The two step system Generalized Method of Moments (GMM) [10-12] that generates a robust estimator is applied in this study. The reasons as well as the procedure for choosing this method are as follows:

\subsubsection{Why the Two-Step System Generalized Method of Moments (GMM)?}

Many reasons justify the use of this method, reasons such as:

- To control for endogeneity problem because some explanatory variables may not be fully exogenous (for instance per capita GDP and residential combustion emissions variables may be endogenous since the use of fuels types may be associated with households economic conditions).

- The time dimension ( $\mathrm{T}=16)$ of the panel dataset is shorter and country dimension $(\mathrm{N}=44)$ is larger. 
- To remove the time-invariant country-characteristics (fixed effects). Time-invariant country heterogeneity, such as geography, may be correlated with the explanatory variables (for example, one may think that people of Sub-Saharan African (SSA) countries located in more forested areas are likely to use wood and charcoal as fuels in their households). The fixed effects are contained in the error term in Equation (1), which consists of the unobserved time-invariant country-specific effects, $\delta_{i}$ and the observation-specific errors, $\varepsilon_{i t}$.

- To control for autocorrelation, which may rise because of the presence of the lagged dependent variable $\ln (Y)_{i t-1}$ (lagged health expenditure variable, $\operatorname{lnHEPC}(-1)$, $\operatorname{lnOOPPTHE}(-1)$, $\operatorname{lnHEPUBTHE}(-1))$.

The Arellano-Bond estimator was designed for small time period (T) and large panel (N) [14]. Considering [47], we employ the system GMM estimations methods because, according to [48,49], it simultaneously controls for the unobserved country-level heterogeneity, autocorrelation and endogeneity. Based on $[50,51]$, we use two-step efficient estimation to remove the time invariant heterogeneity $[48,49,52,53]$. System GMM instruments the differenced lag dependent variable with lagged levels, and also instruments the levels with lagged differences.

\subsubsection{Assumptions and Tests to Meet Them}

The method considers the assumptions that the error term is not serially correlated. Hence, disturbances in the equations are uncorrelated with the instrumental variables, which are the lagged levels of the series after the equation has been first-differenced to eliminate country specific effects.

The Hansen-J test is used to check the validity of the instruments. The test has a null hypothesis of "the instruments as a group are exogenous". Therefore, the higher the $p$-value of the Hansen-J statistic, the better the results.

The Arellano-Bond test is used to investigate autocorrelation. The test has a null hypothesis of "no autocorrelation" and is applied to the differenced residuals. The test for AR (2) in first differences is more important because it will detect autocorrelation in levels.

Therefore, the instruments are validated using the Hansen-J test for exogenous instruments and the Arellano-Bond test for autocorrelation.

\subsubsection{How Was Two-Step System Generalized Method of Moments (GMM) Chosen?}

We first used both the Arellano-Bond two-step system GMM and the Arellano-Bond two-step difference GMM, which are previously described in the background section. The choice of one of these two models depends on the one having the highest efficiency. The efficiency in turn is based on the result of the Hansen-J test; the higher the $p$-value of the Hansen-J statistic, the better the results, hence the better the model. After running the regressions, the two-step system GMM appeared to be the most efficient model, hence we reported only the results of its regressions. The results of the Arellano-Bond two-step difference GMM are not reported here in order to save space but are available from the authors upon request, and also because we consider the results of the most efficient model, which is the two-step system GMM.

Finally, we run three different regressions for the three different health expenditure variables that are considered as the dependent variables.

The model is expressed as follows:

$$
\begin{gathered}
\ln (Y)_{i t}=\sum_{f=1}^{h} \beta_{1} \ln (Y)_{i t-f}+\gamma_{1} \ln (X)_{i t-l}+\delta_{i}+\varepsilon_{i t} \\
\mathrm{E}\left[\delta_{i}\right]=\mathrm{E}\left[\varepsilon_{i t}\right]=\mathrm{E}\left[\delta_{i} \varepsilon_{i t}\right]=0
\end{gathered}
$$

where $Y$ represents the dependent variables, which are the three health expenditure variables, namely HEPC, OOPPTHE and HEPUBTHE; $X$ stands for the vector of all the explanatory variables; of which 
the main ones are the residential combustion emissions variables (CO, $\mathrm{NO}_{\mathrm{x}}, \mathrm{SO}_{2}$ and $\left.\mathrm{PM}_{2.5}\right)$ and control variables (GDPPCGR, PGR, DAHPC and emissions from all the remaining categories); $\delta_{i}$ are the unobserved time-invariant country-specific effects, whereas $\varepsilon_{i t}$ is the observations error term.

The justification for including GDPPCGR in the model is in order to control for the wealth of countries, since the more the country is poor, the more it likely relies on solid fuels. PGR is included to control for demographic changes because the more the population grows, the more it necessitates health expenditure. DAHPC is added in the model to control for foreign health's aid, since the inflow of foreign aid in the health sector is likely to affect health expenditure, particularly in SSA, where most of the countries rely heavily on foreign aid. Finally, emissions from the remaining categories are included to control for outdoor pollutants.

The analyses are executed using the software STATA (version 14, Stata Corporation, TX, USA).

\section{Results}

Table 1 reports the estimation results of our three different regressions. The estimation results are all valid because the Hansen-J test and the AR (2) test having the null hypotheses of "the instruments as a group are exogenous" and "no autocorrelation", respectively, are overwhelmingly accepted. After running the regressions using emissions data from all the categories, we found that the residential sector was significantly associated with higher health expenditures. The emissions variables of the remaining categories are insignificant and negligible except $\mathrm{PM}_{2.5}$ from transportation $\left(\mathrm{PM}_{2.5 \mathrm{~T}}\right)$, which also has a feeble impact. However, in order to save space, we reported only the results of the significant variables here, but the rest are available from the authors upon request. In addition, since our main interests are the residential combustion emissions variables, we focus more on them in the discussion. The first important observation from Table 1 is that the health expenditure variables are not stable in SSA. They significantly depend on their lagged values, whose coefficients' elasticities approach unity. This implies that if HEPC, OOPPTHE and HEPUBTHE increase by one percentage point this year, ceteris paribus, they will increase by $0.822,0.875$ and 0.698 percentage points, respectively, the next year.

Table 1. Dynamic panel data estimation, two-step system GMM.

\begin{tabular}{|c|c|c|c|}
\hline Variable & lnHEPC & lnOОРРТНЕ & lnHEPUBTHE \\
\hline $\ln \mathrm{HEPC}(-1)$ & $0.822 * * *(0.007)$ & & \\
\hline $\operatorname{lnOOPPTHE~}(-1)$ & & $0.875^{* * *}(0.001)$ & \\
\hline $\operatorname{lnHEPUBTHE~}(-1)$ & & & $0.698^{* * *}(0.000)$ \\
\hline $\operatorname{lnCO}$ & $0.189^{* * *}(0.000)$ & $0.291^{* * *}(0.001)$ & $0.129 * *(0.032)$ \\
\hline $\ln \mathrm{NO}_{x}$ & $0.072 *(0.090)$ & $0.115 *(0.083)$ & $0.062 * *(0.048)$ \\
\hline $\ln \mathrm{PM}_{2.5}$ & $0.201^{* * *}(0.000)$ & $0.308^{* * *}(0.000)$ & $0.175 * *(0.027)$ \\
\hline $\operatorname{lnSO} 2$ & $0.059 *(0.055)$ & $0.093^{* *}(0.011)$ & $0.008 *(0.063)$ \\
\hline GDPPCGR & $0.107^{* *}(0.042)$ & $0.149^{* * *}(0.000)$ & $0.085^{* * *}(0.000)$ \\
\hline PGR & $0.122 * *(0.014)$ & $0.188 *(0.054)$ & $-0.092(0.133)$ \\
\hline $\operatorname{lnDAHPC}$ & $0.066 *(0.078)$ & $-0.065 *(0.071)$ & $0.113 * *(0.015)$ \\
\hline $\ln \mathrm{PM}_{2.5 \mathrm{~T}}$ & $0.059 *(0.081)$ & $0.084^{* *}(0.035)$ & $0.028 *(0.069)$ \\
\hline Constant & $0.027^{* *}(0.036)$ & $0.021^{* * *}(0.008)$ & $0.043 *(0.082)$ \\
\hline Observations & 704 & 704 & 704 \\
\hline Countries & 44 & 44 & 44 \\
\hline \multicolumn{4}{|c|}{ Diagnostic Tests (Results of Tests to Meet the Assumptions) } \\
\hline AR(1) [ $p$-value] & 0.032 & 0.012 & 0.005 \\
\hline $\operatorname{AR}(2)[p$-value $]$ & 0.236 & 0.380 & 0.395 \\
\hline $\begin{array}{c}\text { Hansen-J test } \\
\text { [ } p \text {-value }]\end{array}$ & 0.185 & 0.324 & 0.193 \\
\hline
\end{tabular}

$p$-values are in parenthesis; ${ }^{* * *}$ significant at $1 \%$; ${ }^{* *}$ significant at $5 \%$; ${ }^{*}$ significant at $10 \%$; lnVariable means logarithm of the variable; lnVariable $(-1)$ indicates lagged one period of the variable; $\mathrm{PM}_{2.5 \mathrm{~T}}$ means $\mathrm{PM}_{2.5}$ from transportation and GMM refers to Generalized Method of Moments. 
We assess the effectiveness of residential combustion variables on per capita health expenditure to have the aggregate impact, and find that all of them are significantly and positively associated with HEPC. An increase of $1 \%$ in the emissions of $\mathrm{CO}, \mathrm{NO}_{x}, \mathrm{PM}_{2.5}$ and $\mathrm{SO}_{2}$ augment HEPC by $0.189,0.072$, 0.201 and 0.059 percentage points, respectively.

Then, we split health expenditures into public health expenditures and private out-of-pockets health expenditures, all as shares of total health expenditures, and run different regressions in order to have a more clear idea about the residential combustion emissions and specific categories health expenditures nexus. In relation to the public component, the coefficients of $\mathrm{CO}, \mathrm{NO}_{\mathrm{x}}, \mathrm{PM}_{2.5}$ and $\mathrm{SO}_{2}$ are significant with $0.129,0.062,0.175$ and 0.008 as respective elasticities. These indicate that when residential $\mathrm{CO}, \mathrm{NO}_{\mathrm{x}}, \mathrm{PM}_{2.5}$ and $\mathrm{SO}_{2}$ emissions increase, government spending on healthcare also increases. Furthermore, the residential combustion emissions variables are all significantly and positively affecting OOPPTHE. The increase of $1 \%$ in $\mathrm{CO}, \mathrm{NO}_{\mathrm{x}}, \mathrm{PM}_{2.5}$ and $\mathrm{SO}_{2}$ is associated with a $0.291,0.115,0.308$ and 0.093 percentage point increase, respectively, in OOPPTHE. An important remark is that the magnitudes of the effects of the residential combustion emissions are statistically higher on OOPPTHE than on HEPUBTHE. These findings are worrying because in this region the out of pocket health care expenditures are determined by household incomes, while household incomes are low and private insurance is on a small scale. In this situation, if someone has to cover his/her medical expenses out of his/her income, the economic conditions of the household may be worsened and could push the household toward poverty. Therefore, a good and effective public health system of financing health care is needed in SSA in order to help the poor in their health expenditure coverage.

\section{Conclusions}

This paper aims to contribute to the ecological and health economics literature regarding the factors determining health expenditures. After controlling for other variables (including ambient emissions from all the other categories) that influence health expenditures in the three different regressions, results show that residential combustion was associated with significant and higher health expenditures in SSA. The magnitudes of the effects of the residential emissions variables are statistically higher on the out-of-pocket health expenditure than on the others.

There are many implications of our findings, and, to some extent, different from those of the previous works.

Firstly, the implementations of effective public health and environmental health policies that encourage the switching toward the access and use of cleaner fuels or improved cookstoves by households in SSA is crucial as they bear the advantage of reducing health care expenditure especially out-of-pocket. Failing to do so may likely result in a deterioration of the economic conditions of the households, since, in this region, the out of pocket health care expenditures is determined by households' incomes while households' incomes are low and the scale of private insurance is small. Thus, if one has to make frequent out-of-pocket payments for his/her healthcare expenditures, his/her chances to fall into poverty would be high.

Secondly, these policies could also yield additional health and social benefits by maintaining people in a better health status and giving incentive to more recreation (as high emissions of air pollutants contribute largely to air pollution that damages the environment). Thus, SSA's health policy makers should consider emissions from residential combustion issues in the determinants of health expenditure.

Furthermore, if health expenditures go up, it will likely be at the expense of other sectors' expenditures such as education because more proportion of healthcare expenditures will be allocated to those affected by air pollutants concentrations from high residential combustion emissions and lesser funds will be available for other sectors.

Improvement in the economic level of a country in SSA could be associated with a reduction in high emissions of air pollutants from residential combustion since households may be more likely to adopt cleaner fuels, other things being constant. 
Finally, as the findings indicate that emissions from residential combustion are associated with higher health expenditures, and also as residential emissions, which are largely dominated by the combustion of solid fuels contribute to the concentrations of indoor and outdoor air pollutants in SSA, as exposure to concentrations of air pollutants from residential emissions is higher within household (for instance, due to differences in ventilation levels, etc.), so we think that this analysis can be extended to the possibility that indoor air pollution from residential combustion caused higher health expenditures in SSA.

However, this study is not left without caveats. Future work using residential combustion emissions' data relating to specific disease expenditures (for example, cataract, asthma, low birth weight, meningitis, etc.) would possibly better capture the residential emissions-health expenditures relations.

Methodologically, health expenditures would be affected by other variables such as funds for environmental protection, educational attainment, etc., which are not considered in the model of this study due to unavailability of data for the SSA countries; therefore, future work taking into account this important aspect will cover crucial issues.

Finally, as emissions neglect the variability of exposures to concentrations (for instance, due to differences in ventilation levels, etc.), and this study couldn't find quantitative data on concentrations of indoor air pollutants for the SSA countries, future studies could try to fill this gap of high importance and investigate the nexus between indoor air pollution and health expenditures.

Acknowledgments: The authors are grateful to the Natural Science Foundation of China (NSFC) No. 41272362/41572315 for the support in carrying out this study. The authors also sincerely express their gratitude to the Academic Editor and the Reviewers who spent their valuable time providing suggestions and constructive comments on the manuscript.

Author Contributions: Deyi Xu designed the study; Boubacar Hamidou Leyla collected the data; Aboubacar Badamassi analyzed the data as well as wrote the manuscript. All authors have approved the final manuscript.

Conflicts of Interest: The authors declare no conflict of interest.

\section{Appendix A}

Table A1. List of countries.

\begin{tabular}{cccc}
\hline Benin & The Gambia & Burundi & Uganda \\
\hline Burkina Faso & Guinea-Bissau & Comoros & Angola \\
\hline Central African Republic & Equatorial Guinea & Djibouti & Botswana \\
\hline Cote d'Ivoire & Mali & Eritrea & Lesotho \\
\hline Cameroon & Mauritania & Ethiopia & Mozambique \\
\hline The Republic of Congo & Niger & Kenya & Malawi \\
\hline The Democratic Republic of Congo & Nigeria & Madagascar & Namibia \\
\hline Cabo Verde & Senegal & Mauritius & Swaziland \\
\hline Gabon & Sierra Leone & Rwanda & Tanzania \\
\hline Ghana & Chad & Sudan & South Africa \\
\hline Guinea & Togo & Seychelles & Zambia \\
\hline
\end{tabular}


Table A2. List of key acronyms and their corresponding meanings.

\begin{tabular}{ll}
\hline \multicolumn{1}{c}{ Acronyms } & \multicolumn{1}{c}{ Corresponding Meanings } \\
\hline SSA & Sub-Saharan Africa \\
$\mathrm{CO}$ & Carbon monoxide \\
$\mathrm{NO}_{\mathrm{x}}$ & Nitrogen oxide \\
$\mathrm{PM}_{2.5}$ & Particulate Matter with aerodynamic diameter less than $2.5 \mu \mathrm{m}$ \\
$\mathrm{PM}_{10}$ & Particulate Matter with aerodynamic diameter less than $10 \mu \mathrm{m}$ \\
$\mathrm{lnSO}_{2}$ & Sulphur dioxide \\
$\mathrm{HEPC}$ & Per Capita Health Expenditure \\
OOPPTHE & Out of Pocket Health Expenditure \\
HEPUBTHE & Public Health Expenditure \\
GDPPCGR & Per Capita GDP Growth Rate \\
PGR & Population Growth Rate \\
DAHPC & Per Capita Development Assistance for Health \\
GMM & Generalized Method of Moments \\
EDGAR & Emissions Database for Global Atmospheric Research \\
IHME & Institute for Health Metrics and Evalution \\
WHO & World Health Organization \\
IEA & International Energy Agency \\
FAO & Food and Agricultural Organization \\
OECD & Organization for Economic Cooperation and Development \\
WDI & World Development Indicators \\
\hline
\end{tabular}

\section{References}

1. Kamila, S.; Kappen, J.; Rysankova, D.; Hyseni, B.; Putti, R.V. Clean and Improved CookIng in Sub-Saharan Africa; World Bank: Washington, DC, USA, 2014.

2. Smith, K.R. Indoor air pollution in developing countries: Recommendations for research. Indoor Air 2002, 12, 198-207. [CrossRef] [PubMed]

3. World Health Organization. Burning Opportunity: Clean Household Energy for Health, Sustainable Development, and Wellbeing of Women and Children; World Health Organization: Geneva, Switzerland, 2016.

4. World Health Organization. Air Quality Guidelines: Global Update 2005: Particulate Matter, Ozone, Nitrogen Dioxide, and Sulfur Dioxide; World Health Organization: Geneva, Switzerland, 2006.

5. Ezzati, M. Indoor air pollution and health in developing countries. Lancet 2005, 366, 104-106. [CrossRef]

6. Ezzati, M.; Kammen, D.M. Indoor air pollution from biomass combustion and acute respiratory infections in Kenya: An exposure-response study. Lancet 2001, 358, 619-624. [CrossRef]

7. Ezzati, M.; Kammen, D.M. Quantifying the effects of exposure to indoor air pollution from biomass combustion on acute respiratory infections in developing countries. Environ. Health Perspect. 2001, 109, 481. [CrossRef] [PubMed]

8. Bruce, N.; Perez-Padilla, R.; Albalak, R. Indoor air pollution in developing countries: A major environmental and public health challenge. Bull. World Health Organ. 2000, 78, 1078-1092. [PubMed]

9. Masera, O.R.; Saatkamp, B.D.; Kammen, D.M. From linear fuel switching to multiple cooking strategies: A critique and alternative to the energy ladder model. World Dev. 2000, 28, 2083-2103. [CrossRef]

10. Arellano, M.; Bond, S. Some tests of specification for panel data: Monte Carlo evidence and an application to employment equations. Rev. Econ. Stud. 1991, 58, 277-297. [CrossRef]

11. Arellano, M.; Bover, O. Another look at the instrumental variable estimation of error-components models. J. Econ. 1995, 68, 29-51. [CrossRef]

12. Blundell, R.; Bond, S. Initial conditions and moment restrictions in dynamic panel data models. J. Econ. 1998, 87, 115-143. [CrossRef]

13. Hansen, L.P. Large sample properties of generalized method of moments estimators. Econ. J. Econ. Soc. 1982, 50, 1029-1054. [CrossRef]

14. Roodman, D. How to Do Xtabond2: An Introduction to Difference and System GMM in Stata; Center for Global Development: Washington, DC, USA, 2006. 
15. Anenberg, S.C.; Horowitz, L.W.; Tong, D.Q.; West, J.J. An estimate of the global burden of anthropogenic ozone and fine particulate matter on premature human mortality using atmospheric modeling. Environ. Health Perspect. 2010, 118, 1189. [CrossRef] [PubMed]

16. Atkinson, R.; Anderson, H.; Strachan, D.; Bland, J.; Bremmer, S.; Ponce de Leon, A. Short-term associations between outdoor air pollution and visits to accident and emergency departments in London for respiratory complaints. Eur. Respir. J. 1999, 13, 257-265. [CrossRef] [PubMed]

17. Boy, E.; Bruce, N.; Delgado, H. Birth weight and exposure to kitchen wood smoke during pregnancy in rural Guatemala. Environ. Health Perspect. 2002, 110, 109. [CrossRef] [PubMed]

18. Brook, R.D.; Franklin, B.; Cascio, W.; Hong, Y.; Howard, G.; Lipsett, M.; Luepker, R.; Mittleman, M.; Samet, J.; Smith, S.C. Air pollution and cardiovascular disease. Circulation 2004, 109, 2655-2671. [CrossRef] [PubMed]

19. Cohen, A.J.; Ross Anderson, H.; Ostro, B.; Pandey, K.D.; Krzyzanowski, M.; Künzli, N.; Gutschmidt, K.; Pope, A.; Romieu, I.; Samet, J.M. The global burden of disease due to outdoor air pollution. J. Toxicol. Environ. Health Part A 2005, 68, 1301-1307. [CrossRef] [PubMed]

20. Hong, Y.-C.; Lee, J.-T.; Kim, H.; Ha, E.-H.; Schwartz, J.; Christiani, D.C. Effects of air pollutants on acute stroke mortality. Environ. Health Perspect. 2002, 110, 187. [CrossRef] [PubMed]

21. Laden, F.; Schwartz, J.; Speizer, F.E.; Dockery, D.W. Reduction in fine particulate air pollution and mortality: Extended follow-up of the Harvard Six Cities study. Am. J. Respir. Crit. Care Med. 2006, 173, 667-672. [CrossRef] [PubMed]

22. Lin, H.-H.; Ezzati, M.; Murray, M. Tobacco smoke, indoor air pollution and tuberculosis: A systematic review and meta-analysis. PLoS Med. 2007, 4, e20. [CrossRef] [PubMed]

23. Mishra, V.; Dai, X.; Smith, K.R.; Mika, L. Maternal exposure to biomass smoke and reduced birth weight in Zimbabwe. Ann. Epidemiol. 2004, 14, 740-747. [CrossRef] [PubMed]

24. Mishra, V.; Retherford, R.D. Does biofuel smoke contribute to anaemia and stunting in early childhood? Int. J. Epidemiol. 2007, 36, 117-129. [CrossRef] [PubMed]

25. World Health Organization. Burden of Disease from Ambient Air Pollution for 2012; World Health Organization: Geneva, Switzerland, 2014.

26. World Health Organization. Burden of Disease from Ambient Air Pollution for 2012-Summary of Results; World Health Organization (WHO): Geneva, Switzerland, 2014.

27. Orozco-Levi, M.; Garcia-Aymerich, J.; Villar, J.; Ramirez-Sarmiento, A.; Anto, J.; Gea, J. Wood smoke exposure and risk of chronic obstructive pulmonary disease. Eur. Respir. J. 2006, 27, 542-546. [CrossRef] [PubMed]

28. Pokhrel, A.K.; Smith, K.R.; Khalakdina, A.; Deuja, A.; Bates, M.N. Case-control study of indoor cooking smoke exposure and cataract in Nepal and India. Int. J. Epidemiol. 2005, 34, 702-708. [CrossRef] [PubMed]

29. Pope, C.A., III; Burnett, R.T.; Thun, M.J.; Calle, E.E.; Krewski, D.; Ito, K.; Thurston, G.D. Lung cancer, cardiopulmonary mortality, and long-term exposure to fine particulate air pollution. JAMA 2002, 287, 1132-1141. [CrossRef] [PubMed]

30. Saha, A.; Kulkarni, P.; Shah, A.; Patel, M.; Saiyed, H. Ocular morbidity and fuel use: an experience from India. Occup. Environ. Med. 2005, 62, 66-69. [CrossRef] [PubMed]

31. Smith, K.R.; Mehta, S.; Maeusezahl-Feuz, M. Indoor air pollution from household use of solid fuels. In Comparative Quantification of Health Risks: Global and Regional Burden of Disease Attributable to Selected Major Risk Factors; World Health Organization: Geneva, Switzerland, 2004; Volume 2, pp. 1435-1493.

32. Zhao, Y.; Wang, S.; Aunan, K.; Seip, H.M.; Hao, J. Air pollution and lung cancer risks in China-A meta-analysis. Sci. Total Environ. 2006, 366, 500-513. [CrossRef] [PubMed]

33. Di Matteo, L.; Di Matteo, R. Evidence on the determinants of Canadian provincial government health expenditures: 1965-1991. J. Health Econ. 1998, 17, 211-228. [CrossRef]

34. Freeman, D.G. Is health care a necessity or a luxury? Pooled estimates of income elasticity from US state-level data. Appl. Econ. 2003, 35, 495-502. [CrossRef]

35. Gbesemete, K.P.; Gerdtham, U.-G. Determinants of health care expenditure in Africa: A cross-sectional study. World Dev. 1992, 20, 303-308. [CrossRef]

36. Gerdtham, U.-G.; Löthgren, M. On stationarity and cointegration of international health expenditure and GDP. J. Health Econ. 2000, 19, 461-475. [CrossRef]

37. Gerdtham, U.-G.; Søgaard, J.; Andersson, F.; Jönsson, B. An econometric analysis of health care expenditure: A cross-section study of the OECD countries. J. Health Econ. 1992, 11, 63-84. [CrossRef] 
38. Hansen, P.; King, A. The determinants of health care expenditure: A cointegration approach. J. Health Econ. 1996, 15, 127-137. [CrossRef]

39. Herwartz, H.; Theilen, B. The determinants of health care expenditure: Testing pooling restrictions in small samples. Health Econ. 2003, 12, 113-124. [CrossRef] [PubMed]

40. Murthy, N.; Ukpolo, V. Aggregate health care expenditure in the United States: New results. Appl. Econ. Lett. 1995, 2, 419-421. [CrossRef]

41. Murthy, N.V.; Okunade, A.A. Managed care, deficit financing, and aggregate health care expenditure in the United States: A cointegration analysis. Health Care Manag. Sci. 2000, 3, 279-285. [CrossRef] [PubMed]

42. Murthy, N.V.; Ukpolo, V. Aggregate health care expenditure in the United States: Evidence from cointegration tests. Appl. Econ. 1994, 26, 797-802. [CrossRef]

43. Jerrett, M.; Eyles, J.; Dufournaud, C.; Birch, S. Environmental influences on healthcare expenditures: An exploratory analysis from Ontario, Canada. J. Epidemiol. Community Health 2003, 57, 334-338. [CrossRef] [PubMed]

44. Narayan, P.K.; Narayan, S. Does environmental quality influence health expenditures? Empirical evidence from a panel of selected OECD countries. Ecol. Econ. 2008, 65, 367-374. [CrossRef]

45. Emissions Database for Global Atmospheric Research. Available online: http://edgar.jrc.ec.europa.eu/ index.php (accessed on 6 July 2017).

46. Crippa, M.; Janssens-Maenhout, G.; Dentener, F.; Guizzardi, D.; Sindelarova, K.; Muntean, M.; Van Dingenen, R.; Granier, C. Forty years of improvements in European air quality: Regional policy-industry interactions with global impacts. Atmos. Chem. Phys. 2016, 16, 3825-3841. [CrossRef]

47. Lu, C.; Schneider, M.T.; Gubbins, P.; Leach-Kemon, K.; Jamison, D.; Murray, C.J. Public financing of health in developing countries: A cross-national systematic analysis. Lancet 2010, 375, 1375-1387. [CrossRef]

48. Roodman, D. A note on the theme of too many instruments. Oxf. Bull. Econ. Stat. 2009, 71, 135-158. [CrossRef]

49. Roodman, D. How to do xtabond2: An introduction to difference and system gmm in stata. Stata J. 2009, 9, 86-136. [CrossRef]

50. Dieleman, J.L.; Graves, C.M.; Hanlon, M. The fungibility of health aid: Reconsidering the reconsidered. J. Dev. Stud. 2013, 49, 1755-1762. [CrossRef]

51. Dieleman, J.L.; Hanlon, M. Measuring the displacement and replacement of government health expenditure. Health Econ. 2014, 23, 129-140. [CrossRef] [PubMed]

52. Hayakawa, K. First difference or forward orthogonal deviation-Which transformation should be used in dynamic panel data models? A simulation study. Econ. Bull. 2009, 29, 2008-2017.

53. Hayakawa, K. A simple efficient instrumental variable estimator for panel AR (p) models when both $\mathrm{N}$ and T are large. Econ. Theory 2009, 25, 873-890. [CrossRef] 